\title{
Airborne study of a multi-layer aerosol structure in the eastern Mediterranean observed with the airborne polarized lidar ALEX during a STAAARTE campaign (7 June 1997)
}

\author{
F. Dulac and P. Chazette \\ Laboratoire des Sciences du Climat et de l'Environnement, Unité Mixte de Recherche CNRS-CEA No.1572, CEA Saclay \\ 709, F-91191 Gif-Sur-Yvette Cedex, France
}

Received: 12 February 2003 - Published in Atmos. Chem. Phys. Discuss.: 15 May 2003

Revised: 20 October 2003 - Accepted: 23 October 2003 - Published: 27 October 2003

\begin{abstract}
We present a case study of tropospheric aerosol transport in the eastern Mediterranean, based on airborne measurements obtained south of Greece on 7 June 1997. Airborne observations (backscattering lidar at $0.532 \mu \mathrm{m}$ with polarization measurements, in situ particle counters/sizers, and standard meteorological measurements) are complemented by monitoring with Meteosat visible and infrared images and a ground-based sun-photometer, air-mass backtrajectory computations, and meteorological analyses. As already observed from ground-based lidars in the Mediterranean region, the vertical structure of the lower troposphere appears complex, with a superposition of several turbid layers from the surface up to the clean free troposphere which is found here above 2 to $4 \mathrm{~km}$ in altitude. The aircraft observations also reveal an important horizontal variability. We identify the presence of depolarising dust from northern Africa in the most elevated turbid layer, which is relatively humid and has clouds embedded. The lowermost troposphere likely contains pollution water-soluble aerosols from eastern continental Greece, and an intermediate layer is found with a probable mixture of the two types of particles. The column optical depth at $0.55 \mu \mathrm{m}$ estimated from Meteosat is in the range $0.15-0.35$. It is used to constrain the aerosol backscattering-to-extinction ratio needed for the backscattering lidar data inversion. The column value of $0.017 \mathrm{sr}^{-1}$ is found applicable to the various aerosol layers and allows us to derive the aerosol extinction vertical profile. The aerosol extinction coefficient ranges from $0.03 \mathrm{~km}^{-1}$ in the lower clean free troposphere to more than $0.25 \mathrm{~km}^{-1}$ in the marine boundary layer. Values are $<0.1 \mathrm{~km}^{-1}$ in the elevated dust layer but its thickness makes it dominate the aerosol optical depth at some places.
\end{abstract}

Correspondence to: F. Dulac

(fdulac@cea.fr)

\section{Introduction}

The Mediterranean Sea is at the interface between three continents and the Atlantic Ocean. Its atmosphere is severely affected by aerosols from a variety of natural and anthropogenic types of continental sources: desert, vegetation, fossil fuel and biomass combustion, industry, etc (e.g. Bergametti et al., 1992; Kubilay and Saydam, 1995; Mihalopoulos et al., 1997; Moulin et al., 1998; Guerzoni et al., 1999; Formenti et al., 2001). Column integrated aerosol data such as those provided by space-borne passive remote sensing instruments are insufficient to derive natural and anthropogenic contributions to the aerosol load. It has been shown for instance that frequent desert dust plumes from northern Africa found over the Mediterranean are lifted over marine or polluted European air masses (Bergametti et al., 1989; Dulac et al., 1992). The vertical structure of the aerosols with elevated dust layers has been observed in southern Europe with ground-based backscattering lidars (Hamonou et al., 1999; Gobbi et al., 2000; Barnaba and Gobbi, 2001; Papayannis et al., 2001; De Tomasi et al., 2003). Observations within the EU-supported Mediterranean Dust Experiment (MEDUSE; Söderman and Dulac, 1998) even revealed a complex dust transport pattern with the systematic superposition of several dust layers from different origins in Africa (Hamonou et al., 1999).

Until recent methodological developments (Sicard et al., 2002; Wandinger and Ansmann, 2002), the ground-based lidars did not allow the observation of the lowermost troposphere which contains a significant part of the column aerosol load (e.g. Marenco et al., 1997). Measurement of the aerosol extinction profile down to the surface required to fly the lidar system (e.g. Karyampudi et al., 1998; Chazette et al., 2001). We report here on the use of an airborne polarized lidar system over the eastern Mediterranean (Fig. 1) within the EU-supported programme Scientific Training and Access to Aircraft for Atmospheric Research Throughout Europe 

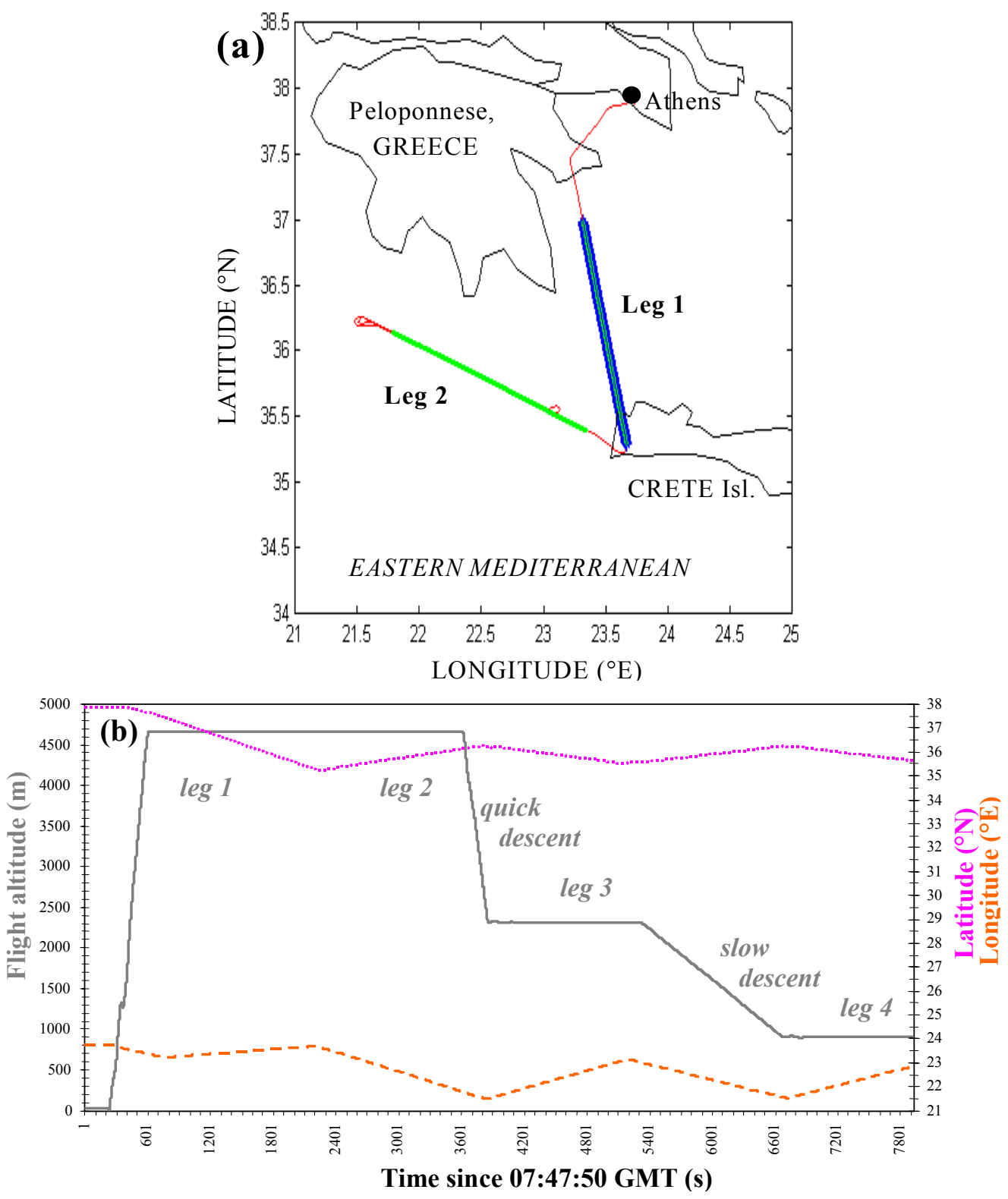

Fig. 1. Flight trajectory from Athens (take-off at 7:52 GMT, 9:52 local time): (a) 2-D projection with emphasis of constant altitude legs with lidar measurements; (b) altitude (line), latitude (dotted line) and longitude (dashed line) during all flight. Leg 1 (08:06-08:25 GMT) and leg 2 (08:28-08:48 GMT) occurred at $4660 \mathrm{~m}$ in altitude with downward remote sensing with the lidar. Leg 3 (08:54-09:15 GMT) and leg 4 (09:39-10:02 GMT) occurred at $2315 \mathrm{~m}$ and $900 \mathrm{~m}$, respectively, on the same track as leg 2 .

(STAAARTE). Model forecasts and real-time monitoring of dust transport with Meteosat (Söderman and Dulac, 1998) allowed us to document a case of complex aerosol vertical structure in the lower troposphere with African dust transport. To discuss the aerosol vertical structure, we combine the STAAARTE airborne remote sensing and in situ particle counting, meteorological data and air-mass back-trajectories, and Meteosat remote sensing. Special emphasis is put on the lidar data. On one side, lidar signal depolarisation by non spherical particles is particularly adapted to the identification of non spherical particles like mineral dust (Iwasaka et al., 1988; Gobbi et al., 2000). On the other side, the aerosol extinction profile is inverted by taking as a constraint the column aerosol optical depth derived from passive remote sensing with Meteosat. 


\section{Observations}

\subsection{Airborne measurements}

Airborne active remote sensing and in situ measurements were performed onboard a twin jet pressurized research aircraft, the Mystère Falcon-20 E5, D-CMET, of the German Aerospace Research Establishment (DLR). Details on this platform can be found at http://www.dlr.de/FB/OP/d-cmet_e. html and http://www.esf.org/eufar/. The flight (No. 2981) took place over seawater off Greece in the morning of 7 June 1997 (take-off at 9:50 local time, 07:50 GMT). Only about two hours corresponding to the first half of the flight were allocated to this work. Dust from Africa and a minimum in the cloud cover were expected there from remote sensing monitoring (Dulac et al., 1997) and predictions of a mesoscale meteorological model including dust transport (Nickovic and Dobricic, 1996; Söderman and Dulac, 1998).

Our flight track is plotted in Fig. 1. Standard meteorological parameters were measured during all flight. During the transit flight from Athens international airport to western Crete along NNW-SSE direction at $4660 \mathrm{~m}$, the downward viewing backscattering lidar system ALEX of the DLR (Renger et al., 1997) was operated between approximately $37^{\circ} \mathrm{N}, 23.3^{\circ} \mathrm{E}$ and $35.25^{\circ} \mathrm{N}, 23.65^{\circ} \mathrm{E}$ (Fig. 1a). Then the aircraft flew back and forth at different levels south of the Peloponnesian peninsula in a ESE-WNW direction between approximately $35.5^{\circ} \mathrm{N}, 23^{\circ} \mathrm{E}$ and $36.25^{\circ} \mathrm{N}, 21.5^{\circ} \mathrm{E}$ (Fig. 1b). There, it performed 3 legs of about $20 \mathrm{mn}$ each at constant altitude $(4660,2315$ and $900 \mathrm{~m})$. During the north-south transit flight (leg 1) and the first east-west leg (leg 2), both at $4660 \mathrm{~m}$ in altitude, the lidar was operated at $10 \mathrm{~Hz}$ and served to identify in real time the vertical structure of the lower troposphere with a vertical resolution of $15 \mathrm{~m}$. We only analysed measurements performed at $532 \mathrm{~nm}$, including the parallel and perpendicular polarizations since the UV and infrared channel measurements of the lidar were not found quantitatively exploitable. To improve the signal to noise ratio, we used a binomial low pass filter (Godin et al., 1999) which yielded a vertical resolution of profiles close to $50 \mathrm{~m}$. The Klett's (1983) forward inversion scheme was used for the lidar inversion in terms of aerosol extinction, assuming a Rayleigh atmosphere in the free troposphere below the aircraft. The aerosol backscatter to extinction ratio (BER) was assumed constant and its value was chosen to adjust the vertically integrated lidar-derived aerosol extinction to the Meteosat-derived aerosol optical depth. Details will be given hereafter. Using the available dual polarisation measurements, we also derived the backscattering depolarisation ratio (Young, 1980).

The raw backscattering and depolarisation signals as a function of altitude were used onboard to identify two layers with distinct aerosol properties at 2.3 and $0.9 \mathrm{~km}$ in altitude where the two subsequent legs were performed for in situ particle counting and sizing measurements (Fig. 1b). Two
Particle Measuring Systems Inc. (PMS) optical probes were operated at $1 \mathrm{~Hz}$ by the GKSS Research Centre: a PCASP100X (diameter range 0.09-3.25 $\mu \mathrm{m}$ ) and a FSSP-100 (2$32 \mu \mathrm{m})$. Each of the PMS probes had 15 channels, but channels of the bigger size range were below or very close to the detection limit for both instruments. We only considered the ranges $0.09-0.325 \mu \mathrm{m}$ (first 6 channels) and $2-10 \mu \mathrm{m}$ (first 4 channels), respectively, which seem reliable during the whole flight. Data were smoothed using a moving averaging window of $35 \mathrm{~s}$.

\subsection{Meteosat data}

Full resolution (2500 lines $\times 2500$ pixels) Meteosat- 6 visible (VIS) and infrared (IR) noon images were acquired daily at 12:00 GMT in the frame of MEDUSE using a Meteosat Primary Data User Station of Data Tools Products (http: //www.data-tools.com) with a 3.1-m antenna. There was unfortunately no data for 5 June. We use the colour quicklook graphical product which was produced operationally as described in Dulac et al. (1997). It is based on a simple colour encoding of sub-sampled data (ISCCP-B1 format, 832 lines $\times 832$ pixels for the full Earth disk) combining both VIS and IR images. It allows a monitoring of dust and clouds at the synoptic scale. Windows from available quick-looks of 7 June and preceding days are shown in Fig. 2. VIS data were further sub-sampled (ISCCP-B2 format, $416 \times 416)$ for MEDUSE real time estimate of the aerosol optical depth at $550 \mathrm{~nm}$ (AOD) over the Mediterranean and the north-eastern Atlantic (not shown), based on the look-up table inversion method extensively described in Moulin et al. (1997a, 1997b) and a VIS sensor calibration following Moulin et al. (1996). The low resolution of such data (about $35 \mathrm{~km} \times 35 \mathrm{~km}$ ) combined to the presence of clouds south of Greece results in the absence of optical depth values in the study area. Available spaceborne POLDER aerosol products (http://smsc.cnes.fr/POLDER/) corresponding to almost coincident observations (10:30 local time) were also tentatively considered, but the relatively low resolution $(18.5 \mathrm{~km} \times 18.5 \mathrm{~km})$ also yields results in not enough pixels for being considered with confidence. Inversion of full resolution (about $6 \mathrm{~km} \times 6 \mathrm{~km}$ ) Meteosat images allows a much better spatial coverage in AOD. Such Meteosatderived values in the Mediterranean have been found to be accurate within about \pm 0.06 compared to sun-photometerderived AODs (unpublished data; Dulac and Paronis, 1998). We analysed the full resolution image of 7 June in order to obtain values of AOD in the area flown.

We also processed low resolution IR images using a difference algorithm allowing the detection of dust over Africa by the apparent cooling of the hot surfaces that it produces (Legrand et al., 2001). A warm reference image was computed from a series of 15 successive images taken at the same hour, and the difference between the given image and the reference image was made to detect anomalously cold areas. 

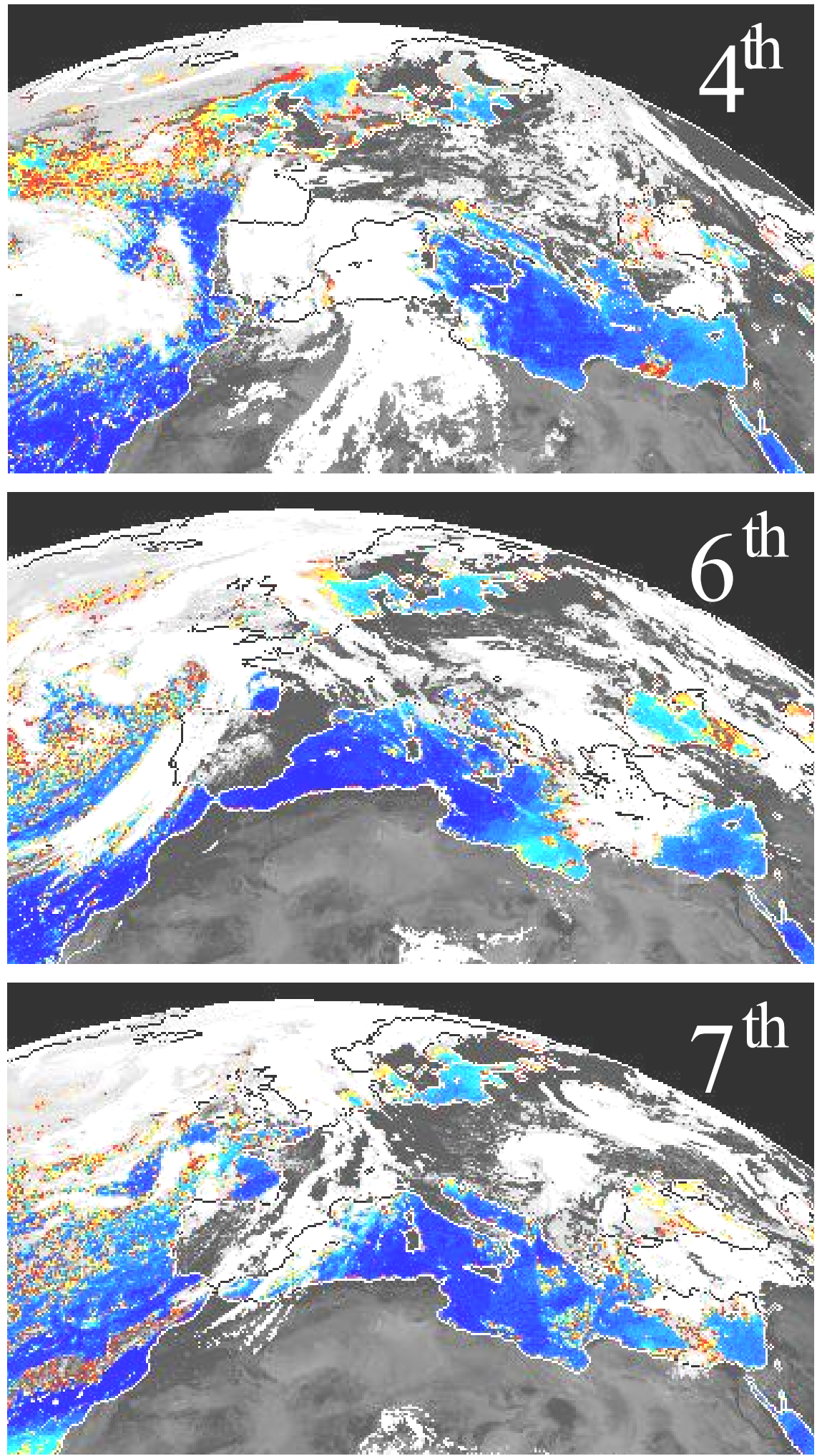

Fig. 2. Meteosat colour quick-look windows for 4, 6 and 7 June ( 5 June image missing). Ocean pixels with clear sky appear in dark blue. The concentration of aerosol over Mediterranean seawater increases from light blue to yellow, orange and red (areas dotted with colours correspond to partly cloudy pixels). Land surfaces appear in dark grey, and clouds in white or very light grey. 
The derived infrared cooling has been found well correlated to horizontal visibility in Africa (Legrand et al., 1994). In both VIS and IR channels, cloudy pixels are detected using thresholds on the local standard deviation.

\subsection{Other data}

We obtained meteorological information from the European Meteorological Bulletin (Deutscher Wetterdienst, 1997) including daily standard charts at 0 GMT (surface only) and 12 GMT, and daily aerological diagrams from rawindsondes launched from Athens operational meteorological station (12 GMT). We also used the TM2-Z atmospheric transport model in reverse mode to compute 3-D, 5-day backtrajectories based on the meteorological analysed winds from ECMWF, Reading, interpolated at the $2.5^{\circ} \times 2.5^{\circ}$ resolution of the model (Ramonet et al., 1996; Chazette et al., 2001). Model layers in the low troposphere are 0-0.4, 0.4$1.2,1.2-2.6,2.6-4.7$ and $4.7-7.3 \mathrm{~km}$. We computed trajectories arriving in the lower troposphere south of Peloponnese $\left(36^{\circ} \mathrm{N}, 22.5^{\circ} \mathrm{E}\right)$, at 0 and $12 \mathrm{GMT}$ on 7 June. The trajectory model disperses, with reverse time and reverse winds, a tracer amount which is released at the end point of the trajectory (Ramonet et al., 1996). Every six hours, the trajectory point is computed as the centre of mass of the tracer plume. The standard deviation of the tracer concentration field was found of the order of $600 \mathrm{~km}$ after three days of transport (Chazette et al., 2001). Finally, the aerosol column optical depth was also monitored at the University of Heraklion coastal atmospheric station at Finokalia in northeastern Crete $\left(35.2^{\circ} \mathrm{N} ; 25.4^{\circ} \mathrm{E}\right)$ with an automated sun-tracking CIMEL Electronique photometer CE-318 (http: //www.cimel.fr/photo/sunph.htm) in the frame of MEDUSE (Paronis et al., 1998). We used measurements at 440 and $670 \mathrm{~nm}$ to derive the Angström spectral exponent and AOD at $550 \mathrm{~nm}$ for comparison with results derived from Meteosat and the lidar. Triple measurements were taken in order to detect cloud contamination based on short term variations in solar light transmission. Relative errors in optical depth and Angström exponent are discussed in Hamonou et al. (1999). They are generally of the order of a few percent for $\mathrm{AOD}>0.1$.

\section{Results and discussion}

3.1 Meteorological situation and column aerosol optical depth

Meteosat quick-look images (Fig. 2) illustrate that a lowpressure system crossed the whole basin from west to east in a few days, which is a typical situation for dust export from Africa to southern Europe (Moulin et al., 1998). Few sun-photometer-derived AODs are available at Finokalia due to clouds from 4-7 June. We find that AOD at $550 \mathrm{~nm}$ was below 0.1 with an Angström exponent of 1 or more from

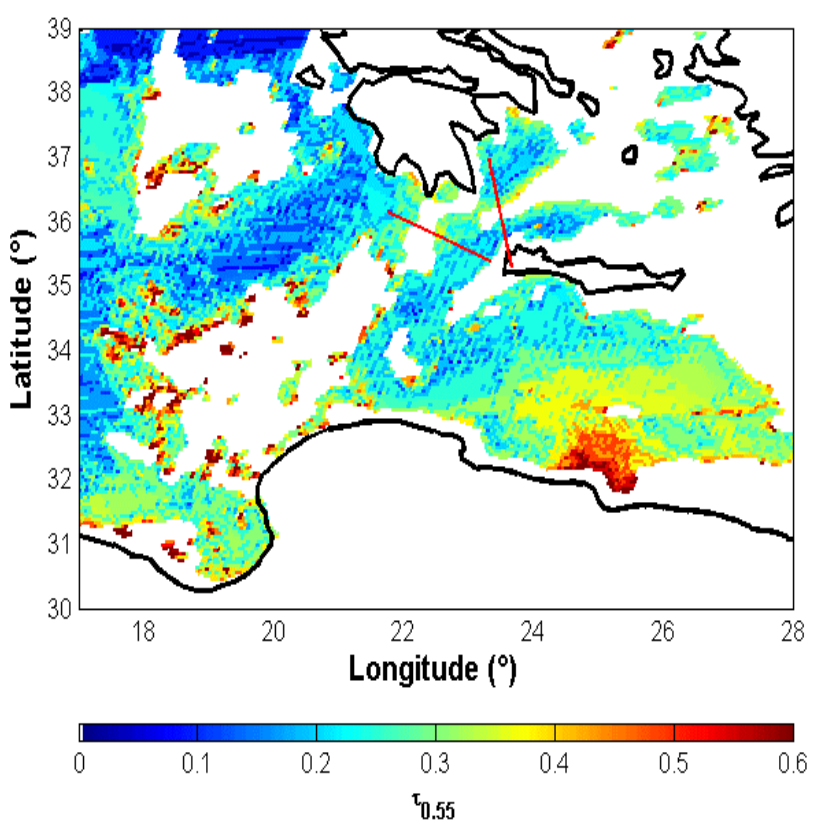

Fig. 3. Distribution of the aerosol optical depth at $550 \mathrm{~nm}$ over clear seawater on 7 June 1997, 11:45 GMT, as derived from the full resolution noon Meteosat VIS image. Masked pixels (land, coastal waters or cloud contamination) are in white and approximate coastlines are drawn in black. Reported in red are the tracks of the airborne legs 1 and 2, which were performed more than three hours earlier than the Meteosat image.

4-6 June. A value of the order of 0.2 with an Angström exponent of about 0.5 can be speculated on 7 June from very few points. The former situation is typical of background and the latter is typical of an African dust plume from Africa (Paronis et al., 1998). A rain with a high pH of about 6.7 occurred in Finokalia (N. Mihalopoulos, personal communication), which is characteristic of a high desert dust content (Loÿe-Pilot et al., 1986). Meteosat products confirm the presence of dust in the south of the eastern Mediterranean basin on 6 and 7 June. The turquoise colour off Libya on June-6 quick-look (Fig. 2) corresponds to AODs of about 0.4. Figure 3 displays AOD results from the full resolution Meteosat image of 7 June. Values of more than 0.3 are found in the clear part of the basin off Egypt but a distinct aerosol plume oriented SW-NE is visible in the flight area, and was crossed by the track of legs $2-4$. AOD values in the plume are of about 0.25 but the central part is masked. This is the sign of large local heterogeneities likely due to clouds.

Figure 4 shows the potential temperature $\left(\theta_{p}\right)$ and relative humidity $(R H)$ profiles obtained south of the Peloponnesian peninsula with the aircraft. Temperature inversions and humidity maxima are found at about 1.3 and $2.3 \mathrm{~km}$ in altitude (Fig. 4a). It must be noted, however, that horizontal variability is large (Fig. 4b). During the flight at $4660 \mathrm{~m}$ from Athens (leg 1), relative humidity ranges between $66 \%$ and $55 \%$ in the 


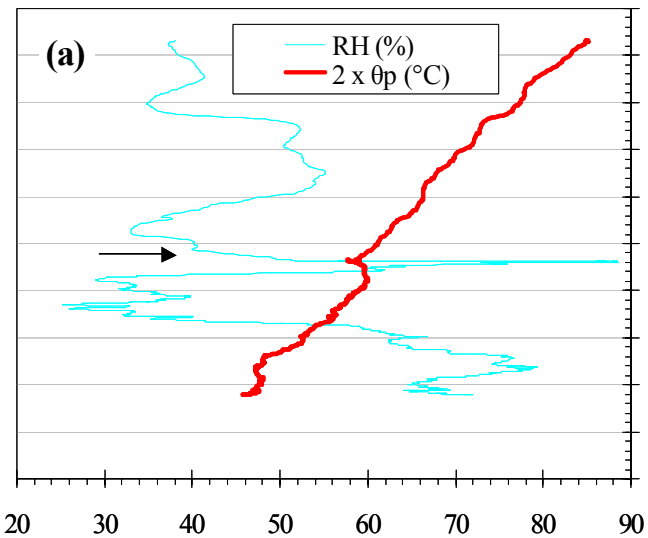

Relative humidity (\%) and potential temperature $\left({ }^{\circ} \mathrm{C}, \mathrm{x} 2\right)$

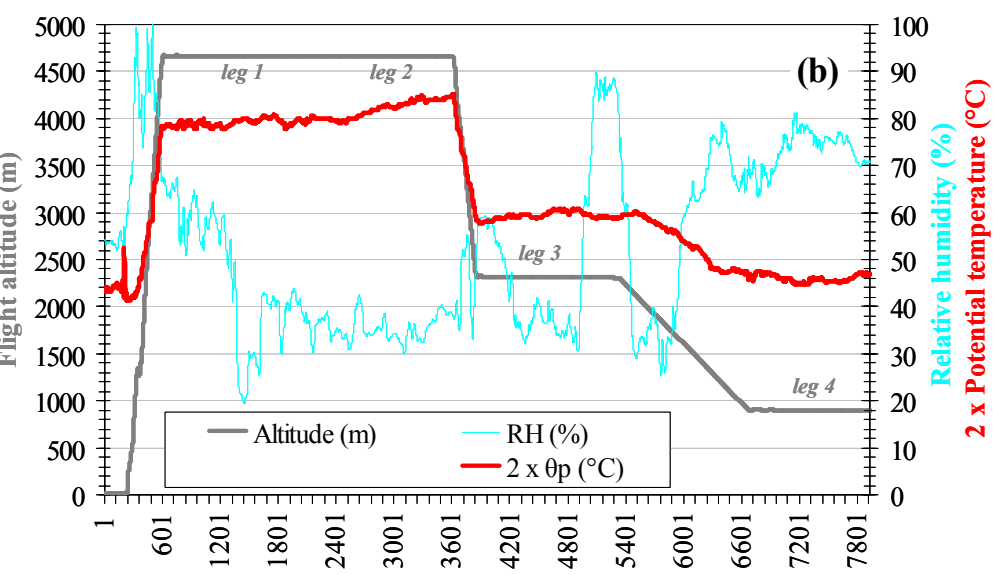

Time since 07:47:50 GMT (s)

Fig. 4. Potential temperature $\left(\theta_{p}\right)$ and relative humidity $(R H)$ measured during the flight in the early morning of 7 June 1997 : (a) profiles during the descents of the aircraft south of the Peloponnese from leg 2 to leg 3 and from leg 3 to leg 4; note that there is a geographical discontinuity (about $200 \mathrm{~km}$ ) between the beginning and the end of leg 3 at the altitude of $2315 \mathrm{~m}$ (arrow); (b) chronological values together with the flight altitude during all flight.

northernmost part and then decreases sharply down to values of $19.5 \%$ (minimum at $36.40^{\circ} \mathrm{N}$ ). Values between $30 \%$ and $45 \%$ are found during the rest of leg 1 and leg 2 at this altitude. During the descent to $2315 \mathrm{~m}$, RH stays between $35 \%$ and $40 \%$ down to $3870 \mathrm{~m}$ and then slightly increases. Values of $50-55 \%$ are found down to $3020 \mathrm{~m}$ followed by a transition to a dryer layer with a minimum of $33 \%$ at $2600 \mathrm{~m}$. This dry layer is found between $21.9^{\circ} \mathrm{E}$ and $22.8^{\circ} \mathrm{E}$ during leg 3 at $2315 \mathrm{~m}$ (with $R H$ values ranging between $30 \%$ and $42 \%$ ) and at about the same longitude between 2180 and $1660 \mathrm{~m}$ during the descent (minimum of $25 \%$ ). However, a relative maximum of $60 \%$ in $R H$ is found in the westernmost part of leg 3 and another one at $90 \%$ in the easternmost part. Below $1550 \mathrm{~m}$ and during all leg 4 at $900 \mathrm{~m}, R H$ is relatively high with values between 63 and $81 \%$. At take-off in Athens, RH is low $(50-55 \%)$ at the surface and increases with height in the MBL.

Wind speed and direction during the flight are plotted in Fig. 5. Near Athens, northerly winds were found at the surface and up to the altitude of leg 1 with a shift in direction from NNE at the ground to NNW at high altitude. Wind speed increased from a few $\mathrm{m} \mathrm{s}^{-1}$ near the surface up to 12 $16 \mathrm{~m} \mathrm{~s}^{-1}$ in altitude. During leg 1 wind intensified and regularly shifted $\mathrm{W}$ when going south so that high WNW wind was encountered at $4660 \mathrm{~m}$ over western Crete. During leg 2 WNW wind remained high and shifted back to NW. During the quick descent to the altitude of leg 3 , wind speed dropped to $5 \mathrm{~m} \mathrm{~s}^{-1}$. During leg 3 back towards Crete at $2315 \mathrm{~m}$, the wind changed significantly. Direction varied from NW to WSW with a speed increase from 5 to $12 \mathrm{~m} \mathrm{~s}^{-1}$. During the slow descent down to the altitude of $900 \mathrm{~m}$ of leg 4, wind speed rapidly decreased below $5 \mathrm{~m} \mathrm{~s}-1$ and direction shifted back to north. Between 1700 and $1500 \mathrm{~m}$, a layer with a con- stant NNW wind direction was crossed. Below $1300 \mathrm{~m}$ and during all leg 4 at $900 \mathrm{~m}$ the wind was relatively steady (NE, $\left.4-6 \mathrm{~m} \mathrm{~s}^{-1}\right)$.

\subsection{Aerosol layers}

In agreement with thermodynamical profiles, raw backscattering lidar data (Fig. 6) and depolarisation ratio (Fig. 7) show a complex vertical structure of aerosol layers with much horizontal variability. The upper air below the aircraft shows a very weak aerosol backscattering and a minimum depolarisation ratio close to the value of 0.018 for a molecular atmosphere. This is clearly the free troposphere and it extends down to very variable altitudes along legs 1 and 2, ranging between about $4 \mathrm{~km}$ over western Crete to less than $2 \mathrm{~km}$ a bit farther west $\left(35.8^{\circ} \mathrm{N}, 22.4^{\circ} \mathrm{E}\right)$.

In the northernmost part of the study area (Fig. 6, right), the boundary layer seems relatively aerosol-free. It extends up to more than $2 \mathrm{~km}$, in agreement with the single inversion observed a few hours later at about $2.9 \mathrm{~km}$ in altitude by the 12 GMT rawindsounding from Athens airport $\left(37.88^{\circ} \mathrm{N}\right)$ (not shown). Clouds were present at several altitudes below the aircraft in the eastern part of the study area, but essentially clear sky below the aircraft occurred west of $23^{\circ} \mathrm{E}$ (Figs. 6 and 7, left). In this area, the marine boundary layer (MBL) top varied between 200 and $400 \mathrm{~m}$ in altitude with discontinuities around $35.75^{\circ} \mathrm{N}, 22.5^{\circ} \mathrm{E}$ and at the extreme west $\left(36.1^{\circ} \mathrm{N}, 21.8-21.9^{\circ} \mathrm{E}\right)$. Pixels masked at about $22.5^{\circ} \mathrm{E}$ on the Meteosat-derived AOD image (Fig. 3) likely indicate clouds formed between the morning flight and the Meteosat scanning hour (13:45 local time) due to cloud condensation at the top of the humid layer following convection in these areas of discontinuities of the MBL top. Indeed, apart from 


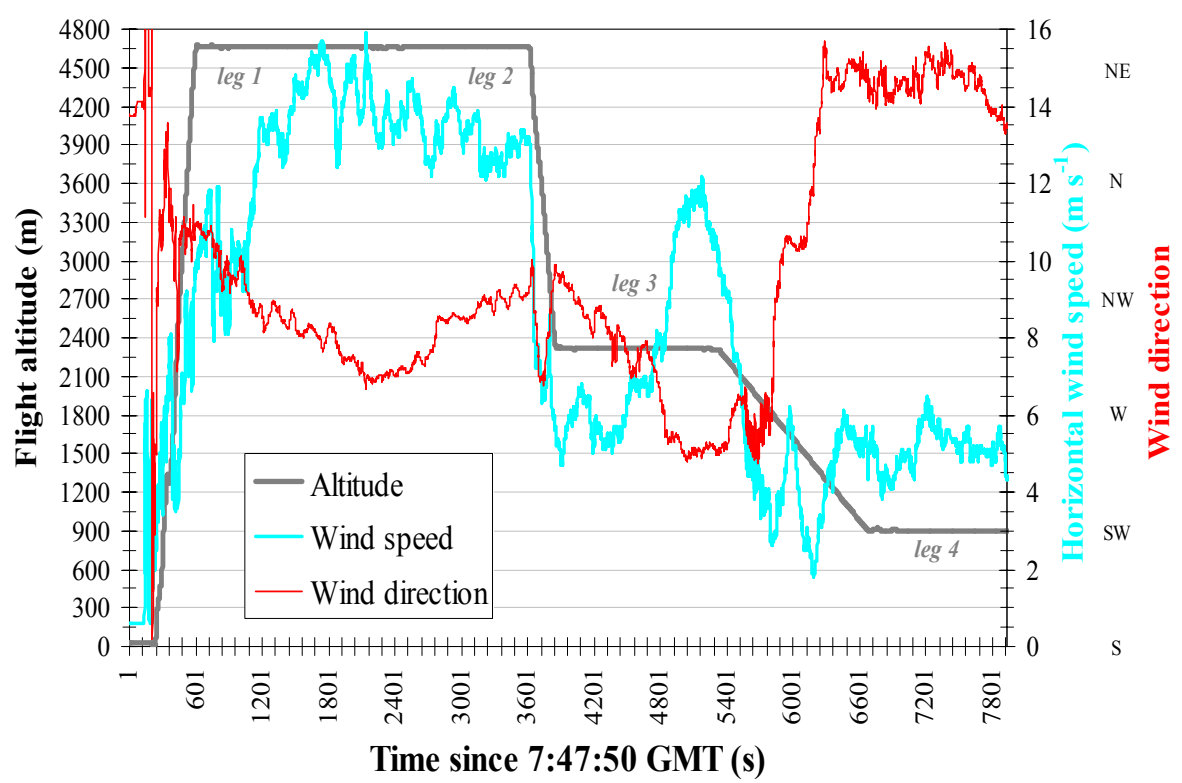

Fig. 5. Horizontal wind speed, wind direction and altitude during the flight.

the cloudy areas near Crete at the end of leg 3, the layer sampled between 1500 and $900 \mathrm{~m}$ in altitude had the highest $R H$ (Fig. 4).

Along leg 4 small fluctuations in $R H$ (between $65 \%$ and $80 \%$; Fig. 4) correspond to variations in depolarisation. Where $R H$ was maximum (Fig. $4 \mathrm{~b}$ ), a relative minimum in depolarisation occurred with similar values to those in the MBL. The relatively lower backscattering and larger depolarisation found between 22 and $23^{\circ} \mathrm{E}$, between leg 4 altitude of $900 \mathrm{~m}$ and the MBL top (Figs. 6 and 7, left) might be due to drier conditions.

In summary, the lidar data (Figs. 6 and 7) allow us to distinguish four main regions in agreement with thermodynamical data. The depolarisation ratio in the MBL is low, in the range 0.020-0.045. Between the free troposphere and down to about $1.2 \mathrm{~km}$, the aerosol is depolarising with a maximum depolarisation ratio $(\sim 0.07-0.09)$ in the humid and turbid air mass near Crete. Intermediate values are found below between this layer and the MBL. The cleaner and nondepolarising air from the free troposphere extends down to about 3 to $4 \mathrm{~km}$ in altitude near western Crete but down to less than $2 \mathrm{~km}$ a bit more west at $22.4^{\circ} \mathrm{E}$. It turns out that potential temperature inversions found at 2.9, 2.3 and $1.3 \mathrm{~km}$ (Fig. 4a) correspond to transitions between aerosol containing layers and the clean free troposphere air, which was temporarily encountered in the course of leg 3 and during the descent to leg 4: the first transition was crossed at about $\left(36.25^{\circ} \mathrm{N} ; 21.25^{\circ} \mathrm{E}\right)$ during the quick descent from leg 2 to leg 3 , and the other two during the slow descent from leg 3 to leg 4 (Fig. 6, left). Combination of Figs. 4b and 6 left shows that the lowest $R H$ of 30-40\% during legs 1, 2 and even 3 were in fact measured in free troposphere air. Small struc- tures between 1.5 and $3 \mathrm{~km}$ in altitude are apparent in Figs. 6 and 7 , in particular in the central part of leg 3 , and reveal mixing between the free troposphere and the depolarising air mass.

Results from the PMS probes are illustrated in Fig. 8. A few of the short term variations observed coincide with small changes in the angles of attack and sideslip of the aircraft during turns and descents, which indicates that PMS measurements appear sometimes affected by the aircraft attitude. This can be explained by a changing sampling efficiency of the probe as a function of particle size. The most striking instance is the minimum in small particle number at $4660 \mathrm{~m}$ which occurred during the turn at constant altitude between leg 1 and leg 2 (8.40-8.44 GMT): a decrease by about a factor 2 in particle number was registered when the aircraft angle of attack only increased from 4.1 to $4.6 \mathrm{deg}$ and the angle of sideslip from 0.75 to $1 \mathrm{deg}$. It is nevertheless difficult to quantify such an influence and this would have needed dedicated tests. Between 9:27 and 9:46 GMT, the small particle number varies only between 43 and 61 in the altitude range $1640-900 \mathrm{~m}$ relatively independently from significant variations in aircraft angles (angle of attack varies from $6.1^{\circ}$ to $4.9 \mathrm{deg}$ during the descent and the beginning of leg 4). Typically the angle of attack was $4.2 \pm 0.1$ deg during legs 1 and 2, $5.2 \pm 0.05$ deg during leg 3 , and between 4.75 and $5 \mathrm{deg}$ during leg 4 . Because of such aircraft attitude variations according to the flight level, the observed evolution of particle concentrations as a function of altitude might be regarded cautiously. Keeping in mind those possible source of errors, the PMS probes show two orders of magnitude variations in both small $(0.1-0.3 \mu \mathrm{m}$ diameter) and large $(2-10 \mu \mathrm{m})$ particle number concentration between the surface near Athens 


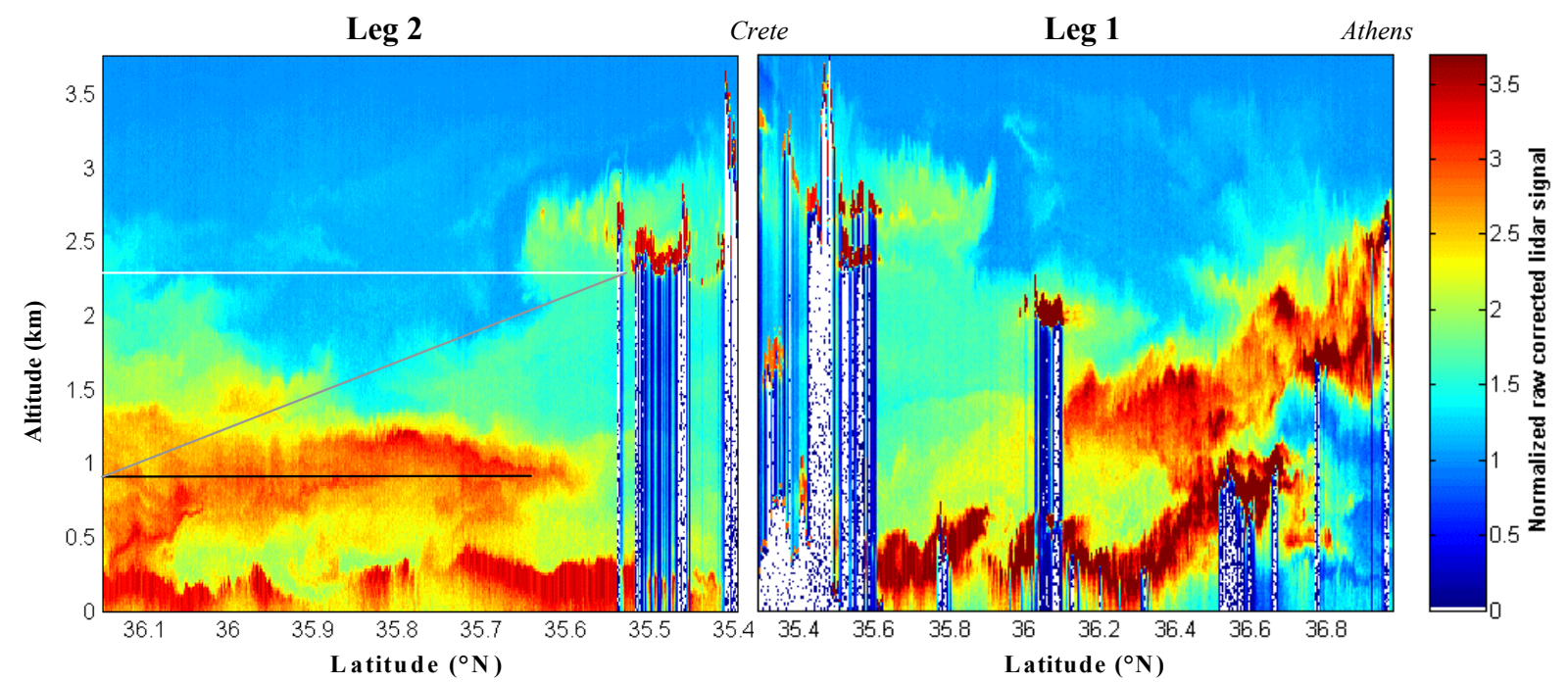

Fig. 6. Geometrically corrected raw lidar data from legs 1 and 2. Location of in situ measurements in lower layers below the track of leg 2 is reported (leg 3 in white, descent in grey and leg 4 in black).

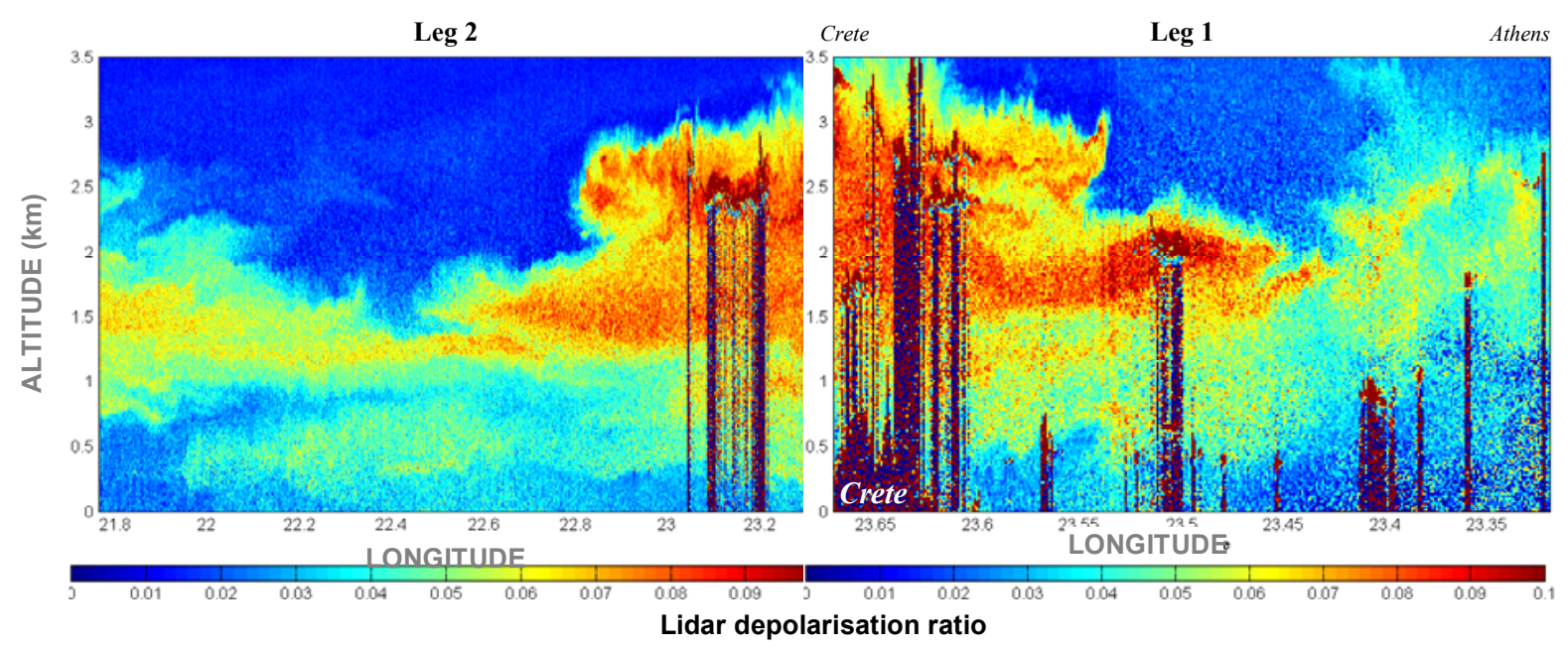

Fig. 7. Lidar depolarisation ratio observed during legs 1 and 2.

and $4660 \mathrm{~m}$. The concentration of small particles $(N)$ was $1300 \mathrm{~cm}^{-3}$ at $100 \mathrm{~m}$ in altitude at take-off. At $4660 \mathrm{~m}, N$ was in the range $15-50 \mathrm{~cm}^{-3}$ during leg 1 with a tendency to decrease towards south. Low values $\left(14-25 \mathrm{~cm}^{-3}\right)$ were also found near Crete during the first half of leg 2. N increased by a factor 2 between 23.1 and $23.3^{\circ} \mathrm{E}$ (8:36-8:47 GMT), accompanied by a small increase in the proportion of large particles, which remained relatively constant during the rest of the flight. At $2315 \mathrm{~m}$ (leg 3), $\mathrm{N}$ ranged between 80 and $250 \mathrm{~cm}^{-3}$ with a sharp minimum at $42 \mathrm{~cm}^{-3}$ at $22.8^{\circ} \mathrm{E}$ in a cell of clean free troposphere air encountered just before entering the depolarising and backscattering air-mass (Figs. 6 and 7 , left). The largest values $\left(>175 \mathrm{~cm}^{-3}\right)$ during leg 3 were found in its westernmost part, in air containing depo- larising aerosol. The small-scale variations found in the rest of the leg seem due to the dilution of the depolarising layer by the free troposphere already mentioned. At $900 \mathrm{~m}$ (leg 4), $\mathrm{N}$ ranges between about 400 and $750 \mathrm{~cm}^{-3}$. The minimum at the end of leg 4 coincides with a small change in the horizontal wind direction, and maxima correspond to minima in depolarisation. The ratio between fine and large particles (Fig. 8) increases with altitude: it is the lowest near Athens and highest values are found during the high altitude legs 1 and 2; the low altitude leg 4 at $900 \mathrm{~m}$ shows intermediate values and a transition between both levels is observed during leg 3 at $2315 \mathrm{~m}$. The similarity between the ratio of fine to large particles between the end of leg 3 and leg 4 (Fig. 8) together with the fact that both air masses show high $R H$ 


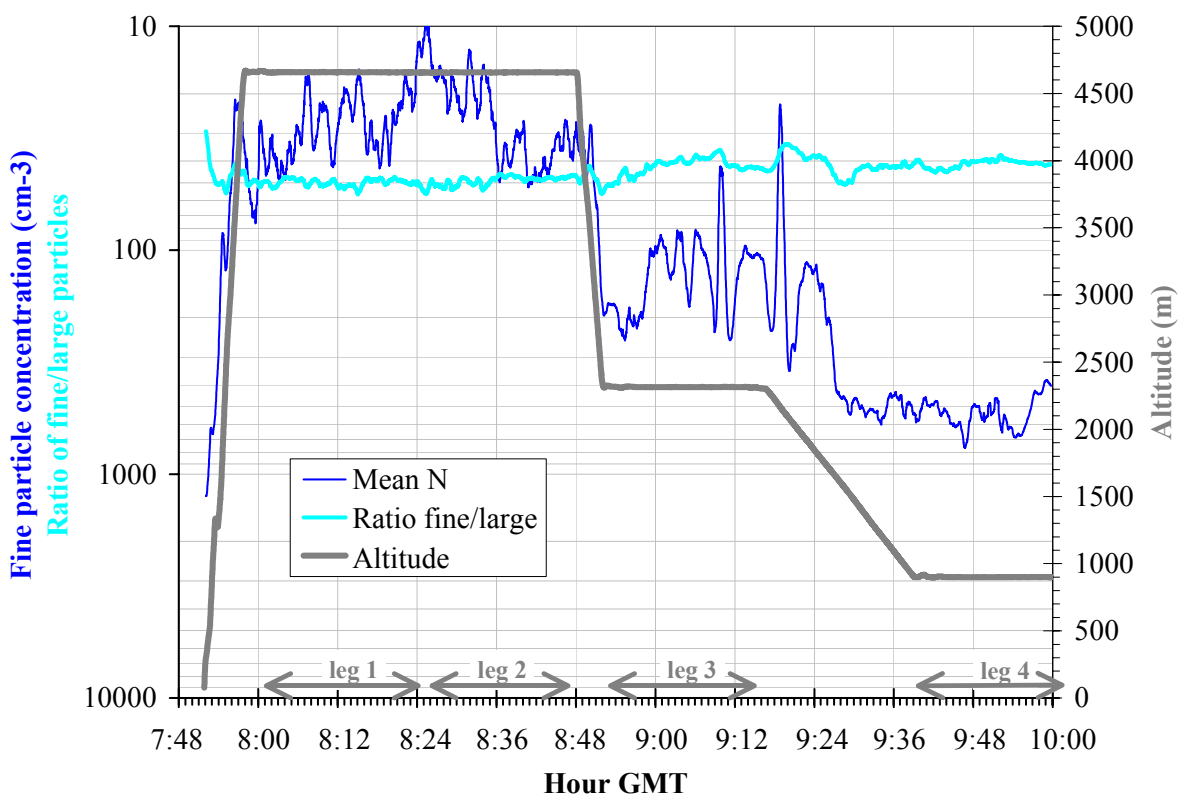

Fig. 8. Concentration of fine particles $(0.1-0.3 \mu \mathrm{m}$ in diameter) and ratio between fine and large $(2-10 \mu \mathrm{m})$ particles (right axis; note that the scale is inverted), and flight altitude (left axis) along the flight.

(Fig. 4b) suggest that turbid air encountered at the end of leg 3 was advected from below by convection.

Figure 9 presents some examples of small particle size distributions obtained at different instants during the flight. It illustrates that the short term variability in size distribution increases when the concentration decreases, likely due to an increase in the relative uncertainty. Noteworthy, the size distributions taken in the depolarising air during leg 3 seem to have a distinct flat shape between 0.1 and $0.3 \mu \mathrm{m}$, whereas other distributions show a steep decrease in particle number with increasing size in this range.

\subsection{Aerosol sources and transport}

All computed back-trajectories arrive south of Greece from the north-west by the Ionian Sea and coastal Greece, as illustrated in Fig. 10. This is consistent with the airborne measurements of the wind direction (NW; Fig. 5) for the upper trajectories. NE winds observed between 1300 and $900 \mathrm{~m}$ are not well represented by the intermediate trajectory. It is likely that average transport between 400 and $1200 \mathrm{~m}$ at the $2.5^{\circ}$ scale of the model was dominated by NW winds since the rawindsounding from Athens confirms that wind direction shifted to NW below $900 \mathrm{~m}$. In the MBL, the trajectories arriving at 0 and 12 GMT are short and essentially marine or coastal. We conclude that low polarisation values, corresponding to spherical particles, at low altitude (Fig. 7) are due to sea salts and water-soluble secondary aerosols which adsorb water vapour and generally dominate in the MBL. The trajectory finishing at $1900 \mathrm{~m}$ originates from South Tunisia on 2 and 3 June. Infrared Meteosat data confirm high dust concentration over South Tunisia and western Libya on 2 and 3 June (Fig. 10), a region known to be a desert dust source for the Mediterranean atmosphere at that season (Moulin et al., 1998). High depolarisation can therefore definitely be attributed to the presence of non spherical mineral dust from north Africa. It is striking that depolarisation is the highest in the elevated layer of dust near Crete (Fig. 7) despite its high relative humidity (Fig. 4) yielding some clouds (Fig. 6). Trajectories finishing in the two upper layers (2.6-4.7 km and 4.7-7.3 km; not shown) were also over a known dust source region in northern Algeria (Western Grand Erg) on 2 June, at only about $2 \mathrm{~km}$ in altitude. But infrared images show that no dust emission occurred in this area, which explains the low aerosol content above $3 \mathrm{~km}$ in altitude.

The trajectory finishing at $0.8 \mathrm{~km}$ in altitude (humid and turbid layer) follows approximately the same way than the trajectory at $1.9 \mathrm{~km}$, but it is shorter and the air mass was already off Tunisia over the central Mediterranean when dust was raised. It spent its last two days over the eastern coast of Greece where it had the opportunity to encounter continental sources of water soluble particles. Intermediate depolarisation (Fig. 7, left) in this humid layer is consistent with a mixing of dust particles and water-soluble particles. We conclude that this intermediate layer contains a mixture of dust particles and marine polluted particles. Horizontal and vertical variability visible in Figs. 6, left, and 7, left, probably result from changes in the respective influence of the two types of particles. 


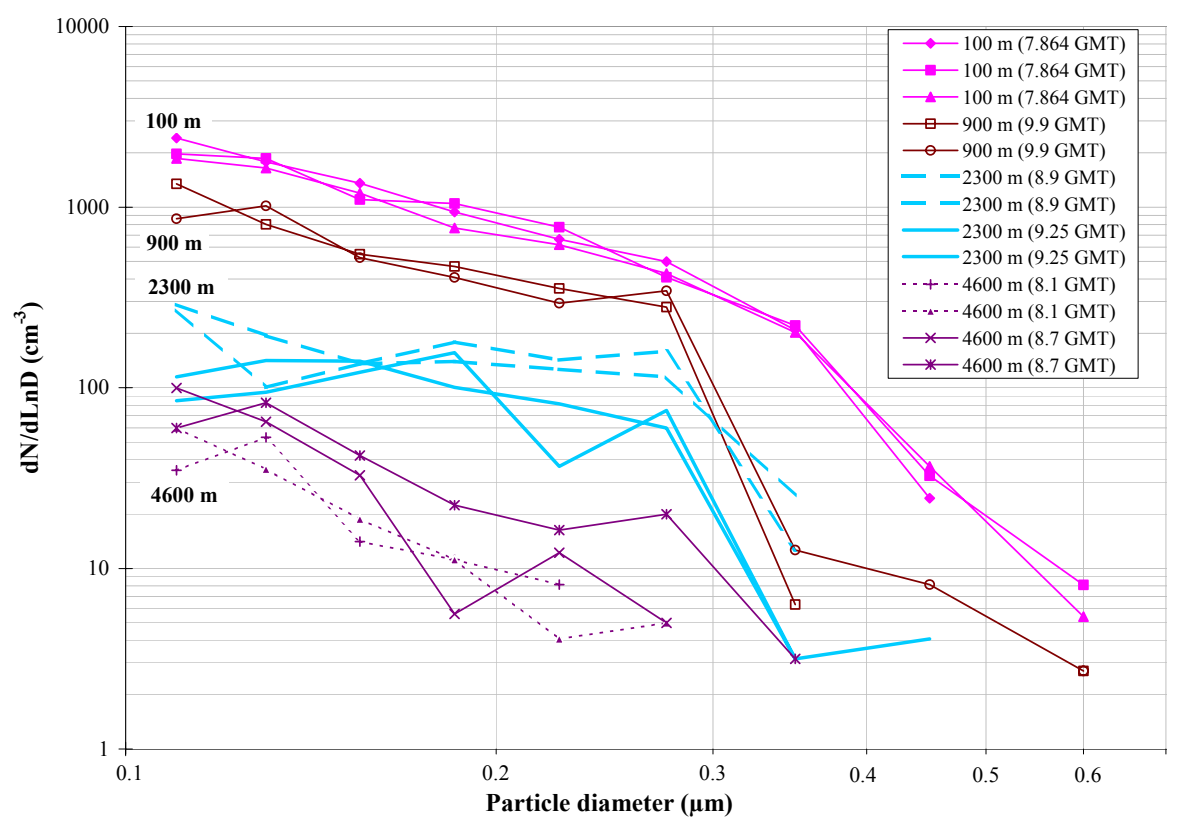

Fig. 9. Examples of particle size distributions measured in situ at different altitudes with the PCASP (1 Hz data). Size ranges of the different counting channels are $0.10-0.12,0.12-0.14,0.14-0.17,0.17-0.20,0.20-0.25,0.25-0.30,0.30-0.40,0.40-0.50$, and $0.50-0.70 \mu \mathrm{m}$.

\subsection{Aerosol extinction profiles}

Retrieval of the aerosol extinction profile from the backscattering lidar measurements requires the knowledge of the ratio (so called BER) between aerosol backscatter and extinction coefficients (Klett, 1983; Fernald, 1984). This ratio depends on the aerosol-type (i.e. size distribution and refractive index) and can consequently vary with height. Relatively large errors in the extinction profile may result from assuming a vertically constant value (e.g. Sasano et al., 1985). In the absence of direct information on the BER profile, a columnar average BER value may be adjusted when an independent measure of the aerosol optical depth is available so that the vertical integral of the lidar-derived aerosol extinction coefficient matches this optical depth (Welton et al., 2000; Stephens et al., 2001; Chazette, 2003). We constrained the columnar BER value by comparing the vertically integrated lidar-derived extinction $\left(\tau_{0.532}\right)$ with the independent Meteosat-derived aerosol optical depth data $\left(\tau_{0.55}\right.$; Fig. 3$)$. Given respective uncertainties in aerosol optical depth retrievals, the difference in wavelengths is small enough to be neglected. Uncertainties in the determination of the aerosol extinction coefficient have three main causes: the statistical fluctuations of the measured signal, the uncertainty in BER, and the uncertainty resulting from the chosen reference altitude. The lidar signal uncertainty followed a Poisson law that is a function of the number of photons backscattered to the telescope. Here our signal to noise ratio is higher than 10 and this error sources is negligible compared to the others. The reference altitude is taken in the free troposphere where no aerosol is present (the decrease of the backscattered signal as a function of altitude closely follows a Rayleigh atmosphere) and the residual relative error on the extinction coefficient due to the use of a climatologic value of the molecular scattering is less than $5 \%$. The major source of error is linked to the choice of the BER, assumed constant with height (Marenco et al., 1997).

The scanning by Meteosat was performed at about 11:45 GMT so that there is a lag of 3 to 4 hours between lidar and Meteosat measurements. With winds of $5 \mathrm{~m} \mathrm{~s}^{-1}$ or more (Fig. 5), this is a long enough time lag to prevent an exact matching of both results, but short enough to consider that the ranges of $\tau$ from the lidar and from Meteosat should be similar. Meteosat-derived aerosol optical depth sections along the tracks of lidar measurements (first two legs) are plotted in Fig. 11 (top). Discrete variations in $\tau_{0.55}$ from one pixel to the next reflect the limited digitisation of the Meteosat signal, which yields by itself an uncertainty of \pm 0.03 on $\tau_{0.55}$. Values between 0.15 and 0.26 are found along leg 1 track with a possibly cloud-contaminated maximum of 0.36 for a pixel adjacent to the central cloud band. Along the track of leg 2, values range between 0.18 and 0.36. Clouds seen by Meteosat (Fig. 3) were not yet present during the airborne flight in the early morning. The best agreement with the lidar was obtained by considering a BER of $0.017 \mathrm{sr}^{-1}$ (Fig. 11, centre). Following a Monte Carlo approach as in Chazette (2003), we estimate that the relative uncertainty on $\tau_{0.55}$ from Meteosat yields an uncertainty of $\pm 0.005 \mathrm{sr}^{-1}$ on the BER. The resulting relative uncertainty on the extinction coefficient is $\sim 35 \%$. The evolution of the vertical profile 


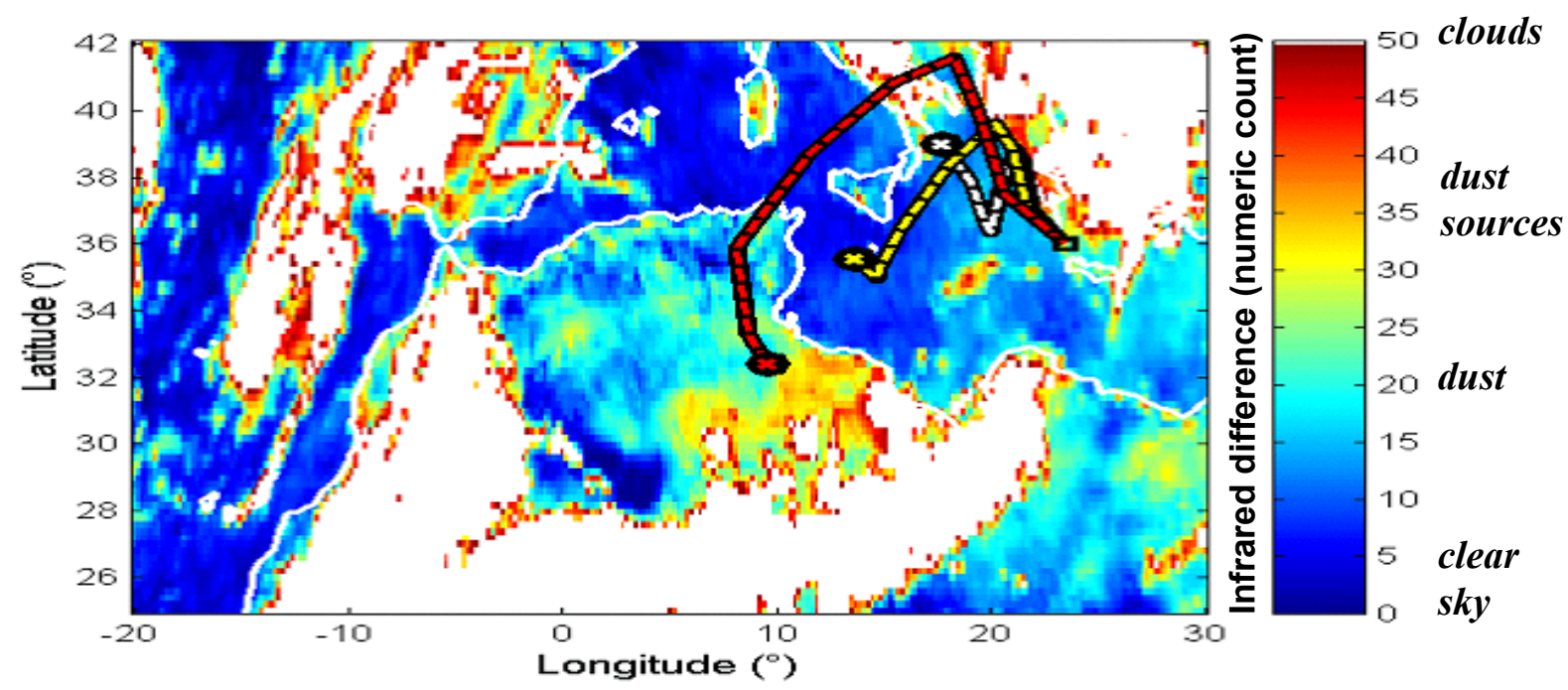

Fig. 10. Meteosat infrared difference image of 3 June 12:00 GMT, and 4-days air mass trajectories arriving at $\left(36^{\circ} \mathrm{N}, 23.5^{\circ} \mathrm{E}\right)$ in the flight area on 7 June 12:00 GMT (white: layer 0-0.4 km; yellow: $0.4-1.2 \mathrm{~km}$; red: $1.2-2.6 \mathrm{~km}$ ).

of aerosol extinction along the lidar legs is also plotted in Fig. 11 (bottom). Results indicate that the extinction coefficient in the dust layer is relatively low $\left(<0.1 \mathrm{~km}^{-1}\right)$ compared to the intermediate layer and the boundary layer. Values up to more than $0.25 \mathrm{~km}^{-1}$ are found in the MBL.

It may be questioned whether the columnar BER value of $0.017 \mathrm{sr}^{-1}$ is applicable to the various aerosol layers encountered since the errors propagate down in altitude in the profile inversion process. Relatively larger values are found in the literature for African dust plumes: Chazette et al. (2001) compute a value of $0.035 \mathrm{sr}^{-1}$ from Mie calculations in the Azores region; Powell et al. (2000) and Welton et al (2000) derive a BER of $0.029 \pm 0.004$ and $0.027 \pm 0.007 \mathrm{sr}^{-1}$, respectively. But Léon et al. (2003) derive lower values of 0.018 and $0.024 \mathrm{sr}^{-1}$ in elevated dust layers during a Saharan outbreak off west Africa. More recently, Mattis et al. (2002) used the Raman lidar technique to measure the BER value of elevated dust layers during two episodes over Germany. Indeed, the additional detection of Raman backscatter by $\mathrm{N}_{2}$ molecules provide a mean to measure separately backscatter and extinction profiles (Ansmann et al., 1992). They report BER values between 0.013 and $0.025 \mathrm{sr}^{-1}$. Liu et al. (2002) and Murayama (2002) also report layer averaged BER in ranges $0.018-0.024$ and $0.022-0.025 \mathrm{sr}^{-1}$, respectively, for Asian dust over Japan. Radiative model calculation indicate that lower values than expected from Mie computations for dust particles can in fact be attributed to non-sphericity effects (Liu et al., 2002; Mattis et al., 2002). For instance Ackermann (1996) computes BER values of $0.040-0.050 \mathrm{sr}^{-1}$ based on the Mie theory but Barnaba and Gobbi (2001) compute smaller values of $0.020-0.028 \mathrm{sr}^{-1}$ at $500 \mathrm{~nm}$ for nonspherical dust aerosols. Finally, De Tomasi et al. (2003) recently reported Raman lidar observations (351-382 nm) of elevated Saharan dust layers over southern Italy for two dust episodes in May 2001. They find average BER values in the UV of $0.018-0.020 \mathrm{sr}^{-1}$ and a range of $0.013-0.025 \mathrm{sr}^{-1}$. Our value appears therefore realistic for the dust layer.

Regarding the lowermost troposphere, we are not aware of BER estimates for the eastern Mediterranean. Values reported for maritime aerosol are large $\left(0.030-0.070 \mathrm{sr}^{-1}\right.$; Ackerman, 1998; Doherty et al., 1999; Franke et al., 2001) but the eastern Mediterranean lower troposphere is known to be severely impacted by continental pollution (e.g. Mihalopoulos et al., 1997). Anderson et al. (2000) report BER values for polluted aerosols in Illinois down to $0.014 \mathrm{sr}^{-1}$ and Chazette et al. (2002) report larger value of $0.018 \mathrm{sr}^{-1}$ for Paris urban area. In the Maldives Islands, southwest of India, aerosols of the lowermost $1000 \mathrm{~m}$ of the tropospheric column also show small BER values during winter monsoon. Values down to $0.010 \mathrm{sr}^{-1}$ were measured under the influence of Asian pollution (in particular due to soot carbon) during the February-March 1999 INDOEX intensive field phase with averages of $0.020 \pm 0.008 \mathrm{sr}^{-1}$ (Franke et al., 2001). On the southwestern coast of India (Goa), Chazette (2003) also reports an average value of $0.028 \pm 0.01 \mathrm{sr}^{-1}$ in February 1999 . Comparable particulate soot carbon concentrations are found in the eastern Mediterranean (Sciare et al., 2002) and the north tropical Indian Ocean (Cantrell et al., 2000) due to continental influence and our value finally appears also quite realistic for the polluted MBL aerosol. However, we cannot exclude that the BER was actually not constant in the column.

In Fig. 12 are plotted the local vertical profiles of aerosol extinction coefficient and lidar depolarisation obtained during leg 2 west of Crete at about $35.6^{\circ} \mathrm{N}, 22.9^{\circ} \mathrm{E}$, where polarizing dust particles are found up to about $3 \mathrm{~km}$ (Fig. 7, 

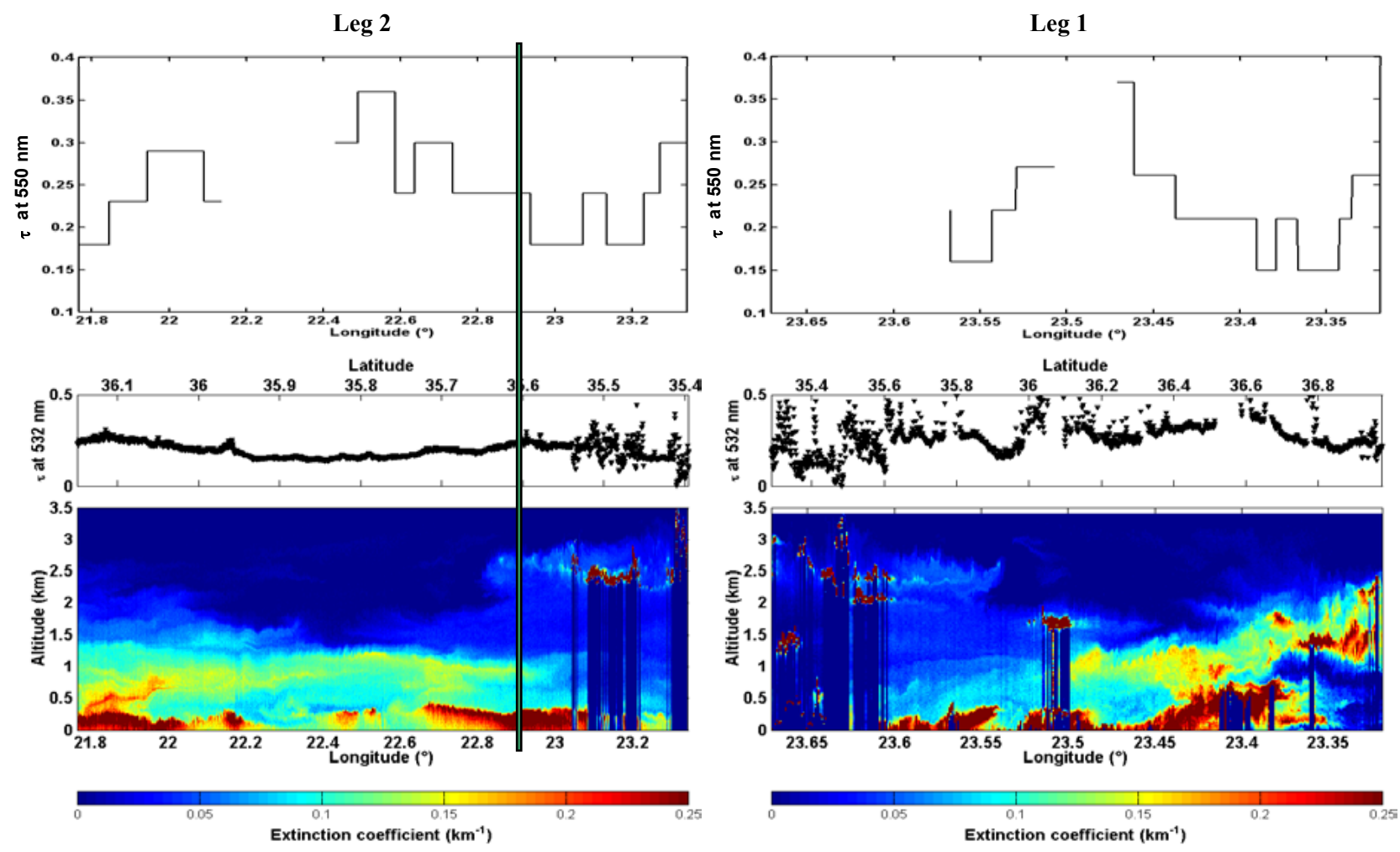

Fig. 11. Aerosol extinction vertical profile and aerosol optical depth along leg 2 (left side) and leg 1 (right side). Top: Meteosat-derived aerosol optical depth; centre: lidar-derived aerosol optical depth; bottom: lidar-derived aerosol extinction profiles. The vertical line on the left refers to Fig. 12.

left). The four aerosol layers are clearly identified. The integrated optical depth is $\sim 0.24$ in good agreement with values derived from Meteosat (and the sun-photometer in Crete). About a third of this optical depth is due to the dust layer $(1.2-3 \mathrm{~km})$. The optical thickness is about 0.1 in the polluted MBL $(0-0.4 \mathrm{~km})$ and 0.06 in the intermediate layer $(0.4-$ $1.2 \mathrm{~km})$ containing pollution and dust particles. A bit farther east $\left(\sim 23.25^{\circ} \mathrm{E}\right)$, extinction in the dust layer dominates the optical depth.

\section{Conclusions}

We have presented a detailed case study of the vertical structure of the low troposphere and associated aerosols observed in the eastern Mediterranean in June 1997. The study combines data from an airborne payload composed of a backscattering lidar with polarization measurements, in situ particle counters/sizers, and standard meteorological measurements, together with Meteosat visible and infrared images, sunphotometer measurements, air-mass back-trajectories and meteorological charts. An original closure of the lidar inversion by satellite-derived aerosol optical depth was presented.

Below the clean free troposphere, three main layers of geographically variable thickness were superimposed which contained distinct aerosols. The lowermost marine boundary layer appeared polluted by water-soluble aerosols likely from eastern Greece. We identified the presence of depolarizing dust particles from the region of south Tunisia and western Libya in an elevated layer found between about $1.2 \mathrm{~km}$ and up to less than 2 to almost $4 \mathrm{~km}$. Clouds were strikingly present in this dust layer, in regions of maximum extinction. Despite the very high relative humidity, maximum depolarization was observed in the vicinity of clouds, likely due to multiple scattering. The intermediate layer likely contained a mixture of the two types of aerosols. We could adjust the column average aerosol backscattering to extinction ratio for the lidar signal inversion by using the Meteosatderived aerosol optical thickness as a constraint. The fitted value of $0.017 \mathrm{sr}^{-1}$ was found realistic for aerosol particles in the different layers from the MBL to the free troposphere. This allowed us to derive the aerosol extinction vertical profile, which revealed that dust particles are responsible for up to more than half of the total aerosol optical depth which ranged between 0.15 and 0.35 . This study illustrates the complex horizontal and vertical structure of aerosols in the lower troposphere and its variability at the regional scale, even in a marine environment. It stresses both the need for aerosol optical depth measurements from passive sensors in 


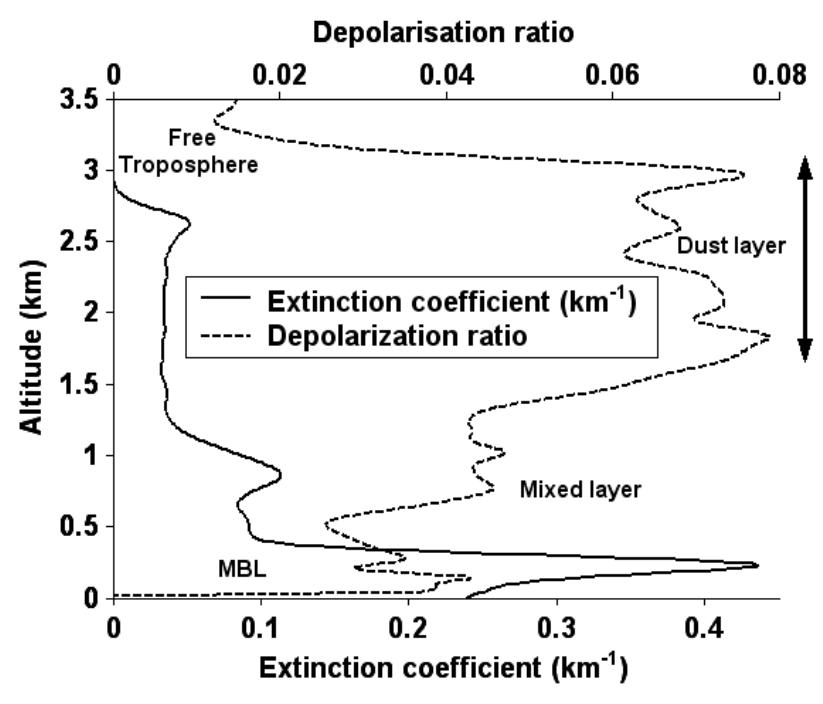

Fig. 12. Example of the vertical profiles of aerosol extinction coefficient and of lidar depolarisation showing the different aerosol layers west of Crete. Location of the profiles is marked on Fig. 11. The "Mixed layer" characterizes the transition region where different aerosol types are mixed.

coincidence with the forthcoming spaceborne backscattering lidar measurements (http://virl.gsfc.nasa.gov/glas/index. html; http://www-calipso.larc.nasa.gov) for data inversion, and the great interest of coincident lidar depolarisation measurements to interpret the data in terms of aerosol types. However, surface-based lidars with Raman backscattering capabilities and/or multi-angular lidar measurements will likely remain most helpful for constraining aerosol extinction profiles from space lidars.

Acknowledgements. M. Krautstrunk, F. Rösler, H. Finkenzeller, H. Brockstieger, A. Giez, D. Zander, M. Wirth, V. Weiß, and others from the DLR flight operation team as well as F. Albers and U. Maixner from GKSS are gratefully acknowledged for their role in the acquisition and pre-processing of airborne data. The STAAARTE campaign was funded by the EU/DGXII programme Training and Mobility of Researchers. The planning of the flight during the campaign was greatly facilitated by J. K. D. Söderman who provided 3D model predictions of dust transport, and by $\mathrm{X}$. Schneider and M. Legrand who performed real-time analyses of Meteosat visible and infrared images, respectively. MEDUSE was funded by the EU/DGXII programme Environment and Climate (contract No. ENV4-CT95-0036). An anonymous reviewer is acknowledged for providing additional relevant references on lidar observations. This is LSCE contribution No. 1026.

\section{References}

Ackermann, J.: The extinction-to-backscattering ratio of tropospheric aerosol: A numerical study, J. Atmos. Oceanic Technol., 15, 1043-1050, 1998.

Anderson, T. L., Masonis, S. J., Covert, D. S., Charlson, R. J., and Rood, M. J.: In situ measurements of aerosol extinction-tobackscatter ratio at a polluted continental site, J. Geophys. Res., 105, 26907-26915, 2000.

Ansmann, A., Wandinger, U., Riebesell, M., Weitkamp, C., and Michaelis, W.: Independent measurement of extinction and backscatter profiles in cirrus clouds by using a combined Raman elastic-backscatter lidar, Appl. Opt., 31, 7113-7131, 1992.

Barnaba, F. and Gobbi, G. P.: Lidar estimation of tropospheric aerosol extinction, surface area and volume: Maritime and desert-dust cases, J. Geophys. Res., 106, 3005-3018, 2001.

Bergametti, G., Gomes, L., Remoudaki, E., Desbois, M., Martin, D., and Buat-Ménard, P.: Present transport and deposition patterns of African dusts to the north-western Mediterranean, in: Paleoclimatology and Paleometeorology: Modern and Past Patterns of Global Atmospheric Transport., edited by Leinen, M. and Sarnthein, M., Kluwer, Dordrecht, 227-251, 1989.

Bergametti, G., Remoudaki, E., Losno, R., Steiner, E., Chatenet, B., and Buat-Ménard, P.: Source, transport and deposition of atmospheric phosphorus over the northwestern Mediterranean, J. Atmos. Chem., 14, 501-513, 1992.

Cantrell, W., Shaw, G., Leck, C., Granat, L., and Cachier, H.: Relationships between cloud condensation nuclei spectra and aerosol particles on a south-north transect of the Indian Ocean., J. Geophys. Res., 105, 15313-15320, 2000.

Chazette, P., David, C., Lefrère, J., Godin, S., Pelon, J., and Mégie, G.: Comparative lidar study of the optical, geometrical, and dynamical properties of stratospheric post-volcanic aerosols, following the eruptions of El Chichon and Mount Pinatubo, J. Geophys. Res., 100, 23 195-23 207, 1995.

Chazette, P., Pelon, J., Moulin, C., Dulac, F., Carrasco, I., Guelle, W., Bousquet, P., and Flamant, P.-H.: Lidar and satellite retrieval of dust aerosols over the Azores during SOFIA/ASTEX, Atmos. Environ., 35, 4297-4304, 2001.

Chazette, P., Randriamiarisoa, H., Sanak, J., Flamant, C., and Pelon, J.: Airborne lidar for the survey of the Paris aerosol production in the frame of ESQUIF program, In Lidar Remote Sensing in Atmospheric and Earth Sciences, edited by Bissonnette, L. R., Roy, G., and Vallée, G., Defence R\&D Canada Valcartier, ValBélair, Canada, Vol. 1, 173-175, 2002.

Chazette, P.: The monsoon aerosol extinction properties at Goa during INDOEX as measured with lidar, J. Geophys. Res., 108, doi 10.1029/2002JD002074, 2003.

De Tomasi, F., Blanco, A., and Perrone, M. R.: Raman lidar monitoring of extinction and backscattering of African dust layers and dust characterization, Appl. Opt., 42, 1699-1709, 2003.

Deutscher Wetterdienst: European Meteorological Bulletin, Deutscher Wetterdienst, Offenbach, Germany, daily publication, June 1997.

Doherty, S. J., Anderson, T. L., and Charlson, R. J.: Measurement of the lidar ratio for atmospheric aerosols with a $180^{\circ}$ backscatter nephelometer, Appl. Opt., 38, 1823-1832, 1999.

Dulac, F., Tanré, D., Bergametti, G., Buat-Ménard, P., Desbois, M., and Sutton, D.: Assessment of the African airborne dust mass over the western Mediterranean Sea using Meteosat data, J. Geo- 
phys. Res., 97, 2489-2506, 1992.

Dulac, F., Hamonou, E., Schneider, X., Moulin, C., Chazette, P., Liberti, G. L., Paronis, D., Lambert, C. E., Legrand, M., Defossez, J. B., Balis, D., Papayannis, A., Ancellet, G., and Mihalopoulos, N.: Meteosat and ground-based optical measurements of desert dust within European project MEDUSE, Proceeding of the 1997 EUMETSAT Meteorological Satellite Data Users' Conference, Publication EUM P21, EUMETSAT, Darmstadt, 549-556, 1997.

Dulac, F. and Paronis, D.: Quantitative remote sensing of aerosols in the Mediterranean region, Contract UE DGXII ENV-CT965057 final report, Dec. 1998.

Fernald, F.G.: Analysis of atmospheric lidar observations: some comments, Appl. Opt., 23, 652-653, 1984.

Formenti, P., Andreae, M. O., Andreae, T. W., Galani, E., Vasaras, A., Zerefos, C., Amiridis, V., Orlovsky, L., Karnieli, A., Wendisch, M., Wex, H., Holben, B. N., Maenhaut, W., and Lelieveld, J.: Aerosol optical properties and large scale transport of air masses: Observations at a coastal and a semiarid site in the eastern Mediterranean during summer 1998, J. Geophys. Res., 106, 9807-9826, 2001.

Franke, K., Ansmann, A., Müller, D., Althausen, D., Wagner, F., and Scheele, R.: One-year observations of particle lidar ratio over the tropical Indian Ocean with Raman lidar, Geophys. Res. Lett., 28, 4559-4562, 2001

Gobbi, G. P., Barnaba, F., Giorgi, R., and Santacasa, A.: Altituderesolved properties of a Saharan dust event over the Mediterranean, Atmos. Environ., 34, 5119-5127, 2000.

Godin, S., Carswell, A., Donovan, D., Claude, H., Steinbrecht, W., McDermid, S., McGee, T., Gross, M. R., Nakane, H., Swart, D. P. J., Bergwerff, J. B., Uchino, O., Von Der Gathen, P., and Neuber, R.: Differential absorption lidar ozone algorithm intercomparison, Appl. Opt., 38, 6225-6236, 1999.

Guerzoni, S., Chester, R., Dulac, F., Herut, B., Loye-Pilot, M. D., Measures, C., Migon, C., Molinaroli, E., Moulin, C., Rossini, P., Saydam, C., Soudine, A., and Ziveri, P.: The role of atmospheric deposition in the biogeochemistry of the Mediterranean Sea, Progr. Oceanog., 44, 147-190, 1999.

Hamonou, E., Chazette, P., Balis, D., Dulac, F., Schneider, X., Galani, E., Ancellet, G., and Papayannis, A.: Characterization of the vertical structure of Saharan dust export to the Mediterranean basin, J. Geophys. Res., 104, 22 257-22 270, 1999.

Iwasaka, Y., Yamato, M., Imasu, R., and Ono, A.: Transport of Asian dust (KOSA) particles; importance of weak KOSA events on the geochemical cycle of soil particles, Tellus, 40B, 494-503, 1988.

Karyampudi, V. M., Palm, S. P., Reagen, J. A., Fang, H., Grant, W. B., Hoff, R. M., Moulin, C., Pierce, H. F., Torres, O., Browell, E. V., and Melfi, S. H.: Validation of the Saharan dust plume conceptual model using lidar, Meteosat, and ECMWF data, Bull. Am. Meteor. Soc., 80, 1045-1075, 1999.

Klett, J. D.: Lidar calibration and extinction coefficients, Appl. Opt., 22, 514-515, 1983.

Kubilay, N. and Saydam, A. C.: Trace elements in atmospheric particulates over the Eastern Mediterranean; concentrations, sources, and temporal variability, Atmos. Environ., 29, 22892300, 1995.

Legrand, M., N'doumé, C., and Jankowiak, I.: Satellite-derived climatology of the Saharan aerosol. Passive Infrared Remote Sens- ing of Clouds and the Atmosphere II, edited by Lynch, D. K., SPIE, 127-135, 1994.

Legrand, M., Plana-Fattori, A., and N'Doumé, C.: Satellite detection of dust using the IR imagery of Meteosat, 1. Infrared difference dust index, J. Geophys. Res., 106, 18 251-18 274, 2001.

Léon, J.-F., Tanré, D., Pelon, J., Kaufman, Y. J., Haywood, J. M., and Chatenet, B.: Profiling of a Saharan dust outbreak based on a synergy between active and passive remote sensing, J. Geophys. Res., 108, doi 10.1029/2002JD002774, 2003.

Liu, Z., Sugimoto, N., and Murayama, T.: Extinction-to-backscatter ratio of Asian dust observed with high-spectral- resolution lidar and Raman lidar, Appl. Opt., 41, 2760-2767, 2002.

Loÿe-Pilot, M.-D., Martin, J.-M., and Morelli, J.: Influence of Saharan dust on the rain acidity and atmospheric input to the Mediterranean, Nature, 321, 427-428, 1986.

Marenco, F., Santacesaria, V., Bais, A. F., Balis, D., di Sarra, A., Papayannis, A., and Zerefos, C.: Optical properties of tropospheric aerosols determined by lidar and spectrophotometric measurements (Photochemical Activity and Solar Ultraviolet Radiation campaign). Appl. Opt., 36, 6875-6886, 1997.

Mattis, I., Ansmann, A., Müller, D., Wandinger, U., and Althausen, D.: Dual-wavelength Raman lidar observations of the extinctionto-backscatter ratio of Saharan dust, Geophys. Res. Lett., 29, doi 10.129/2002GL014721, 2002.

Mihalopoulos, N., Stephanou, E., Kanakidou, M., Pilitsidis, S., and Bousquet, P.: Tropospheric aerosol ionic composition in the Eastern Mediterranean region, Tellus, 49B, 314-326, 1997.

Moulin, C., Lambert, C. E., Poitou, J., and Dulac, F.: Long-term (1983-1994) calibration of the Meteosat solar (VIS) channel using desert and ocean targets, Int. J. Remote Sens., 17, 11831200, 1996.

Moulin, C., Guillard, F., Dulac, F., and Lambert, C. E.: Long-term daily monitoring of Saharan dust load over ocean using ISCCPB2 data, 1. Methodology and preliminary results for 1983-1994 in the Mediterranean, J. Geophys. Res., 102, 16947-16958, 1997a.

Moulin, C., Dulac, F., Lambert, C. E., Chazette, P., Jankowiak, I., Chatenet, B., and Lavenu, F.: Long-term daily monitoring of Saharan dust load over ocean using ISCCP-B2 data, 2. Accuracy of the method and validation using Sun photometer measurements, J. Geophys. Res., 16959-16969, 1997b.

Moulin, C., Lambert, C. E., Dayan, U., Masson, V., Ramonet, M., Bousquet, P., Legrand, M., Balkanski, Y. J., Guelle, W., Marticorena, B., Bergametti, G., and Dulac, F.: Satellite climatology of African dust transport in the Mediterranean atmosphere, J. Geophys. Res., 103, 13 137-13 144, 1998.

Murayama, T.: Optical properties of Asian dust aerosol lofted over Tokyo observed by Raman lidar, in: Lidar Remote Sensing in Atmospheric and Earth Sciences, edited by Bissonnette, L. R., Roy, G., and Vallée, G., Defence R\&D Canada, Val-Bélair, Vol. 1, 331-334, 2002.

Nickovic, S. and Dobricic, S.: A model for long-range transport of desert dust, Mon. Weather Rev., 124, 2537-2544, 1996.

Papayannis, A., Boselli, A., Calpini, B., et al.: Simultaneous observations of free tropospheric Saharan dust layers over Europe monitored by a co-ordinated ground-based lidar network in the frame of the EARLINET project, J. Aerosol. Sci., 32, S389S390, 2001.

Paronis, D., Dulac, F., Chazette, P., Hamonou, E., and Liberti, G. 
L.: Aerosol optical thickness monitoring in the Mediterranean, J. Aerosol Sci., 29, S671-S672, 1998.

Powell, D. M., Reagan, J. A., Rubio, M. A., Erxleben, W. H., and Spinhirne, J. D.: ACE-2 multiple angle micro-pulse lidar observations from Las Galletas, Tenerife, Canary Islands, Tellus, 52B, 652-661, 2000.

Ramonet, M., Roulley, J.-C., Bousquet, P., and Monfray, P.: Radon222 measurements during the TROPOZ II campaign and comparison with a global atmospheric transport model, J. Atmos. Chem., 23, 107-136, 1996.

Renger, W., Kiemle, C., Schreiber, H. G., Wirth, M., and Mörl, P.: Correlative measurements in support of LITE using the airborne backscatter lidar ALEX, in: Advances in Atmospheric Remote Sensing with Lidar, edited by Ansmann, A,. Neuber, R., Rairoux, P., and Wandinger, U., Springer-Verlag, Berlin, 165-168, 1997.

Sasano, Y., Browell, E. V., and Ismail, S.: Error caused by using a constant extinction/backscattering ratio in the lidar solution., Appl. Opt., 24, 3929-3932, 1985.

Sciare, J., Bardouki, H., Moulin, C., and Mihalopoulos, N.: Aerosol sources and their contribution to the chemical composition of aerosols in the Eastern Mediterranean Sea during summertime, Atmos. Chem. Phys. Discuss., 2, 1287-1315, 2002.

Sicard, M., Chazette, P., Pelon, J., Won, J. G., and Yoon, S.-C.: Variational method for the retrieval of the optical thickness and the backscatter coefficient from multiangle lidar profiles, Appl. Opt., 41, 493-502, 2002
Söderman, J. K. D. and Dulac, F.: Monitoring and prediction of the atmospheric transport and deposition of desert dust in the Mediterranean region, Proceeding of the First LAS/WMO International Symposium on Sand and Dust Storms, Damascus, Syrian Arab Republic, Report TD864, World Meteorological Organization, Geneva, 181-186, 1998.

Stephens, G. L., Engelen, R. J., Vaughan, M., and Anderson, T. L.: Toward retrieving properties of the tenuous atmosphere using space-based lidar measurements, J. Geophys. Res., 106, 28143 28 157, 2001.

Wandinger, U. and Ansmann, A.: Experimental determination of the lidar overlap profile with Raman lidar, Appl. Opt., 41, 511514, 2002.

Welton, E. J., Voss, K. J., Gordon, H. R., Maring, H., Smirnov, A., Holben, B. N., Schmid, B., Livingston, J. M., Russell, P. B., Durkee, P. A., Formenti, P., and Andreae, M. O.: Ground-based lidar measurements of aerosols during ACE-2: lidar description, results, and comparisons with other ground-based and airborne measurements, Tellus 52B, 636-665, 2000.

Young, S. A.: Analysis of lidar backscatter profiles in optically thin clouds, Appl. Opt., 32, 7019-7030, 1980. 